\title{
Effect of Processing Temperature on the Properties of a Polyvinyl Chloride Maxillofacial Elastomer
}

\author{
R. YU, A. KORAN, III, and J. M. POWERS \\ School of Dentistry, The University of Michigan, Ann Arbor, Michigan 48109
}

Mechanical properties and color of a plasticized polyvinyl chloride $(P V C)$ maxillofacial elastomer were evaluated at processing temperatures from 140 to $190^{\circ} \mathrm{C}$. The properties were dependent on processing temperature. Specimens prepared at $170^{\circ} \mathrm{C}$ had optimum mechanical properties with minimal discoloration.

J Dent Res 62(10):1098-1100, October 1983

\section{Introduction.}

For maxillofacial prostheses, physical and mechanical properties and color are primary characteristics considered by the prosthodontist in selecting the base elastomer. Ideally, the material that is used to replace lost facial tissues, especially the overlying skin, must duplicate the properties of living tissues and provide an esthetic and lifelike appearance. In recent years, the introduction of stable, resilient, and lifelike materials has made possible the fabrication of esthetic and durable maxillofacial prostheses. Scientific studies dealing with the evaluation of commercial materials have since attracted a great deal of interest. ${ }^{1-5}$

In 1972 , Sweeney and associates ${ }^{1}$ reported the results on three formulations of heat-cured vinyl plastisol elastomers. They concluded that an improved polyvinyl chloride (PVC) formulation was the most satisfactory material for clinical usage. Although the physical properties of these formulations have been evaluated extensively, along with stability under weathering conditions, the relationships among physical properties and color as a function of processing temperature were not reported.

The purpose of this study was to investigate quantitatively the effect of various processing temperatures on the mechanical properties and color of a PVC maxillofacial elastomer. This information should serve as a guideline to clinicians in selecting the proper processing condition for this elastomer in practical applications.

\section{Materials and methods.}

The polyvinyl chloride (PVC) studied was a vinyl plastisol formulation*. Prior to being processed at an elevated temperature, this material was a moderately viscous fluid with a viscosity of approximately $7200 \mathrm{cp}$. The color was milky white, which results from the dispersions of highmolecular-weight PVC particles and several chemical additives in plasticizer ${ }^{1}$. This mixture was mixed thoroughly to assure homogeneity before being cast into sheets in aluminum molds, and being cured at temperatures of 140,150 , $160,170,180$, and $190^{\circ} \mathrm{C}$ in an air-circulating oven. The thermal history of each elastomer processed at each curing

Received for publication April 18, 1983

Accepted for publication June 21, 1983

This investigation was supported by USPHS Grant DE-04136 from the National Institute of Dental Research, National Institutes of Health, Bethesda, MD 20205.

Address reprint requests to Dr. Koran.

Dr. Yu is presently employed at Xerox Corp., Webster, NY 14580.

*Prototype III, Sartomer Industries, Inc., Essington, PA 19029 temperature was monitored constantly and recorded at five-minute intervals by a thermocouple inserted into the body of the aluminum mold.

Mechanical properties of shear strength, ultimate tensile strength, maximum percent elongation, permanent deformation at failure, tear energy, and Shore A hardness were evaluated for samples prepared at the six different temperatures. The shear strength was measured according to ASTM designation D732-46 ${ }^{6}$ with a testing machine ${ }^{+}$. Dumbbellshaped tensile specimens $(0.6 \times 0.2 \mathrm{~cm}$ and gauge length of $3 \mathrm{~cm}$ ) were cut from the elastomer sheets using a precision die and were used to measure ultimate tensile strength and maximum percent elongation at a cross-head speed of $10 \mathrm{~cm} / \mathrm{min}$. The measurements for permanent deformation were made after $24 \mathrm{hr}$ of dimensional recovery following ultimate tensile elongation. Values for permanent deformation were calculated by dividing the increase in sample length after failure by the original length. The resistance to tear propagation was determined by using trouser-shaped specimens $^{7}(7.5 \times 2.5 \times 0.1 \mathrm{~cm})$ at a cross-head speed of $5 \mathrm{~cm} / \mathrm{min}$. The indentation hardness was measured with a tester ${ }^{\dagger}$ with samples $1.0 \mathrm{~cm}$ in thickness.

The specimens for color measurements were $6 \times 4 \times$ $0.35 \mathrm{~cm}$. The effect of curing temperature on color was evaluated quantitatively by measuring the color of each sample with a double-beam, ultraviolet-visible spectrophotometer and an integrating sphere $\S$. Reflectance curves in the visible spectrum were obtained for the samples with both a white and a black background. Luminous reflectance (LR), dominant wavelength (DW), and excitation purity (EP) were calculated for each sample from the reflectance curve using a computer program based upon the CIE Chromaticity Diagram 1931 and Source A. ${ }^{8}$ The translucency of each sample was calculated by dividing the value of $L R$ with a black background by the $L R$ with a white background to determine the contrast ratio (CR), which varies from zero for a transparent sample to one for an opaque sample.

\section{Results.}

The mechanical properties and color of the PVC as a function of processing temperature are tabulated in Tables 1 and 2 , respectively. The means and standard deviations were calculated from five replications. Means were compared statistically by Scheffe's intervals computed from an analysis of variance at a $95 \%$ level of confidence. ${ }^{9,10}$

The mechanical characteristics of PVC (Table 1) were substantially dependent upon the processing temperature. At $140^{\circ} \mathrm{C}$, the mechanical properties were less favorable than those obtained between the temperature range of 170 and $190^{\circ} \mathrm{C}$. The effect of processing temperature on permanent deformation was most pronounced. The value in-

\footnotetext{
${ }^{+}$Model TT-B, Instron Universal Test Instruments, Instron Corp., Canton, MA 02021

The Shore A Instrument \& Manufacturing Co., Inc., Jamaica, NY

$\S$ Acta CIII, Beckman Instruments, Inc, Irvine, CA 92634
} 
creased from $3.6 \%$ at $140^{\circ} \mathrm{C}$ to $40.1 \%$ at $190^{\circ} \mathrm{C}$. The tear energy increased from $2.4 \times 10^{6}$ dynes $/ \mathrm{cm}$ at $140^{\circ} \mathrm{C}$ to $22.5 \times 10^{6}$ dynes $/ \mathrm{cm}$ at $190^{\circ} \mathrm{C}$. The smallest change was seen for Shore $A$ hardness, for which values increased from 43 units at $140^{\circ} \mathrm{C}$ to 53.2 units at $190^{\circ} \mathrm{C}$.

The results for $\mathrm{LR}, \mathrm{CR}, \mathrm{DW}$, and EP (presented in Table 2 ) indicated that the color of the processed PVC was also temperature-dependent. The LR with a white background was 54.4 for samples prepared at $140^{\circ} \mathrm{C}$. This value increased slightly to 61.6 at $170^{\circ} \mathrm{C}$, then decreased to a low of 21.3 at $190^{\circ} \mathrm{C}$, indicating a lightening effect on the sample processed between 140 and $170^{\circ} \mathrm{C}$ and a darkening when processed above $170^{\circ} \mathrm{C}$. When these samples were examined with a black background, values of LR demonstrated a steady drop for the entire temperature range (from 12.7 at $140^{\circ} \mathrm{C}$ to 4.4 at $190^{\circ} \mathrm{C}$ ). The large differences noted in LR for samples measured with the white and the black backgrounds were caused by the translucency of PVC material. The CR was 0.234 for samples processed at $140^{\circ} \mathrm{C}$, decreased to 0.148 at $170^{\circ} \mathrm{C}$, and increased to 0.208 at $190^{\circ} \mathrm{C}$. The PVC was most transparent when processed at $170^{\circ} \mathrm{C}$. No statistical difference in DW was observed for samples processed between 140 and $170^{\circ} \mathrm{C}$, but significant changes were seen for samples processed above $170^{\circ} \mathrm{C}$. The $\mathrm{DW}$ increased from $584.1 \mathrm{~nm}$ at $170^{\circ} \mathrm{C}$ to $610.4 \mathrm{~nm}$ at $190^{\circ} \mathrm{C}$, which represents a shift from yellow to the orange-red region in the color spectrum. The largest color change was noted in the saturation of the samples at higher processing temperatures. The EP increased from 0.177 at $140^{\circ} \mathrm{C}$, to 0.316 at $170^{\circ} \mathrm{C}$, and to 0.857 at $190^{\circ} \mathrm{C}$.

The difficulty of instantaneously raising the plastisol to the desired curing temperature is a result of the heat capacity and heat conductivity of the aluminum mold and the plastisol itself. This limitation is illustrated by typical temperature-time profiles for samples prepared at 140 and $190^{\circ} \mathrm{C}$ in Fig. 1. The entire curing process required a total of $50 \mathrm{~min}$, with $40 \mathrm{~min}$ needed to bring a sample to the desired temperature and an additional ten min at a constant temperature to complete the processing cycle.

\section{Discussion.}

At room temperature, the unprocessed PVC is a moderately viscous, free-flowing liquid mixture. At elevated temperatures, the PVC dispersion swells and dissolves in the plasticizer and subsequently gels as the temperature is lowered. Under experimental observation, $140^{\circ} \mathrm{C}$ was found to be the critical temperature for successful formation of elastomeric gel; the mechanical properties and color of the

TABLE 1

MECHANICAL PROPERTIES OF PVC MAXILLOFACIAL ELASTOMER AS A FUNCTION OF PROCESSING TEMPERATURE

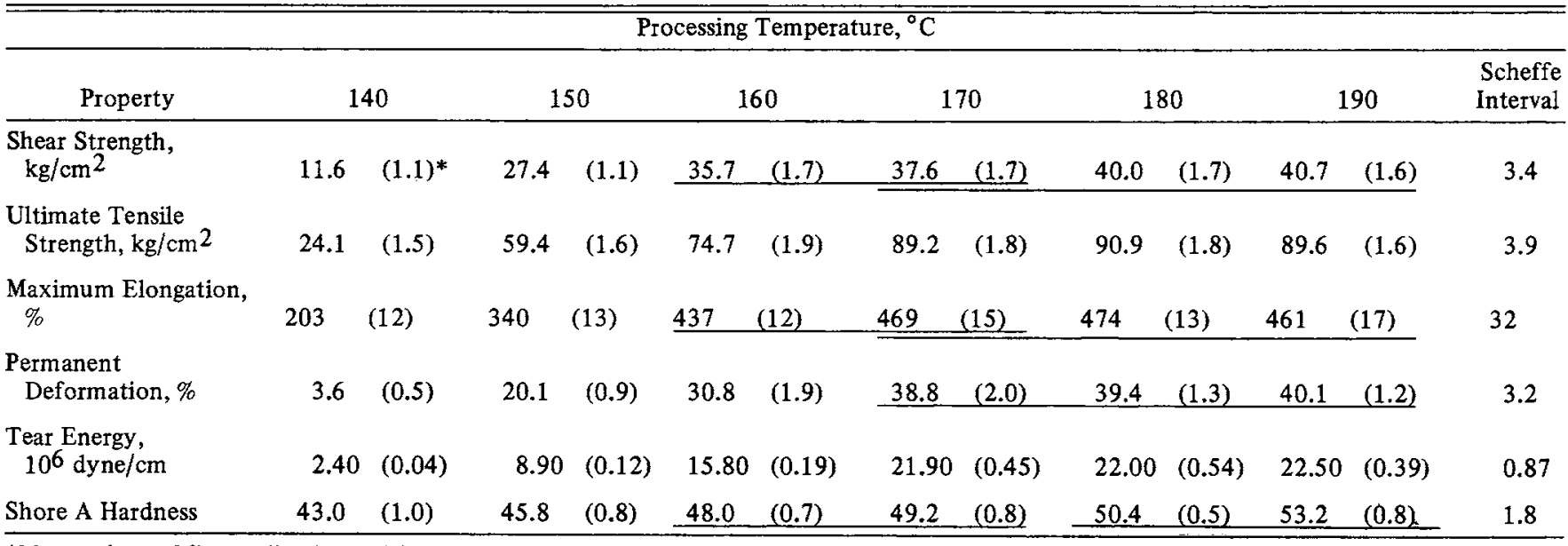

*Mean values of five replications with standard deviations in parentheses.

Underlines indicate no statistical difference.

TABLE 2

COLOR CHARACTERISTICS OF PVC MAXILLOFACIAL ELASTOMER AS A FUNCTION OF PROCESSING TEMPERATURE

\begin{tabular}{|c|c|c|c|c|c|c|c|c|}
\hline \multicolumn{9}{|c|}{ Processing Temperature, ${ }^{\circ} \mathrm{C}$} \\
\hline Contrast Ratio & - & $\begin{array}{c}0.234 \\
(0.009)\end{array}$ & $\begin{array}{c}0.202 \\
(0.005)\end{array}$ & $\begin{array}{c}0.172 \\
(0.005)\end{array}$ & $\begin{array}{c}0.148 \\
(0.005) \\
\end{array}$ & $\begin{array}{c}0.154 \\
(0.005) \\
\end{array}$ & $\begin{array}{c}0.208 \\
(0.013)\end{array}$ & 0.017 \\
\hline Excitation Purity & White & $\begin{array}{c}0.177 \\
(0.007)\end{array}$ & $\begin{array}{c}0.248 \\
(0.005)\end{array}$ & $\begin{array}{c}0.273 \\
(0.009)\end{array}$ & $\begin{array}{c}0.316 \\
(0.012)\end{array}$ & $\begin{array}{c}0.805 \\
(0.009)\end{array}$ & $\begin{array}{c}0.857 \\
(0.010)\end{array}$ & 0.023 \\
\hline
\end{tabular}

* Mean values of five replications and standard deviations in parentheses.

Underlines indicate no statistical difference. 


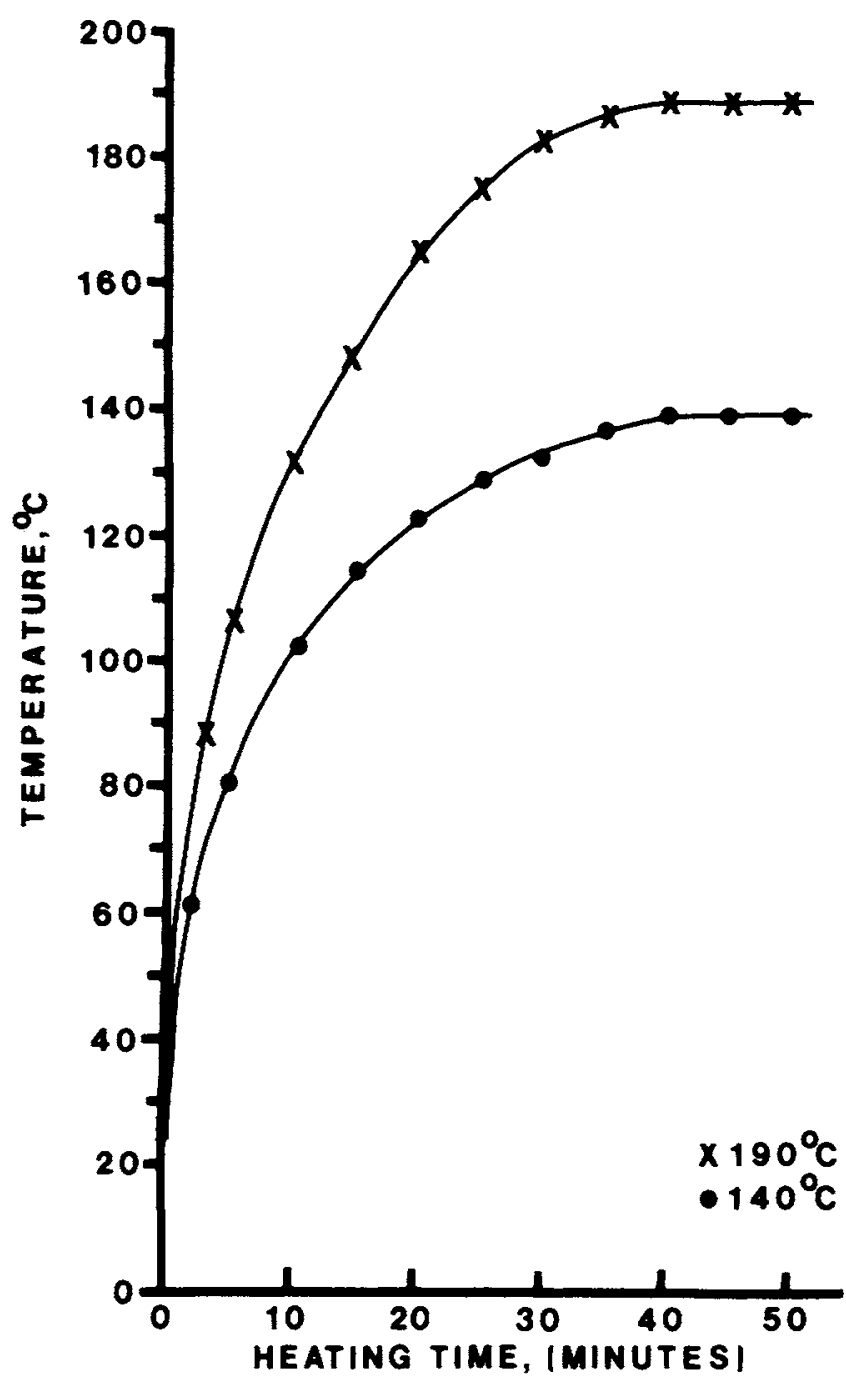

Fig. 1 - Temperature-time relationship for specimens processed at 140 and $190^{\circ} \mathrm{C}$.

elastomer were optimized at $170^{\circ} \mathrm{C}$; above this processing temperature, undesirable discoloration became apparent.

The results indicate that the processing temperature plays an important role in determining the overall mechanical behavior and color characteristics of the elastomer. The low values of shear strength, ultimate tensile strength, maximum percent elongation, permanent deformation, tear energy, and Shore $A$ hardness seen at $140^{\circ} \mathrm{C}$ are the result of incomplete gelation of the elastomer. The samples processed at this temperature were light yellow and slightly opaque. Complete dissolution of the PVC dispersion was observed for samples processed at $170^{\circ} \mathrm{C}$, resulting in the formation of a uniform elastic matrix with improved mechanical strength and little color change. Although the mechanical properties of samples processed at temperatures above $170^{\circ} \mathrm{C}$ did not change significantly, the samples were badiy discolored as a result of the exudation of plasticizer, conjugation of molecular double bonds, and sample decomposition by thermal-oxidative degradation. ${ }^{11}$

\section{Conclusions.}

(1) The mechanical properties and color of the plasticized PVC elastomer were dependent upon the processing temperature.

(2) The optimum mechanical properties and color were obtained at a processing temperature of $170^{\circ} \mathrm{C}$

(3) At processing temperatures above $170^{\circ} \mathrm{C}$, there was little improvement in mechanical properties and considerable discoloration of the elastomer.

\section{Acknowledgment.}

The authors want to express their thanks to Dena $\mathrm{S}$. Dukes for preparing samples and making measurements.

\section{REFERENCES}

1. SWEENEY, W.T.; FISCHER, T.E.; CASTLEBERRY, D.J.; and COWPERTHWAITE, G.F.: Evaluation of Improved Maxillofacial Prosthetic Materials, J Prosthet Dent 27:296305,1972 .

2. KORAN, A. and CRAIG, R.G.: Dynamic Mechanical Properties of Maxillofacial Materials, J Dent Res 54:1216-1221, 1975.

3. YU, R.; KORAN, A.; and CRAIG, R.G.: Physical Properties of Maxillofacial Elastomers Under Conditions of Accelerated Aging, $J$ Dent Res 59:1041-1047, 1980.

4. GONZALEZ, J.B.: Polyurethane Elastomers for Tacial Prostheses, $J$ Pros thet Dent 39:179-187, 1978.

5. CRAIG, R.G.; KORAN, A.; YU, R.; and SPENCER, J.: Color Stability of Elastomers for Maxillofacial Appliances, $J$ Dent Res 57:866-871, 1978.

6. YU, R.; KORAN, A.; and CRAIG, R.G.: Physical Properties of a Pigmented Silicone Maxillofacial Material as a Function of Accelerated Aging, J Dent Res 59:1141-1148, 1980.

7. WEBBER, R.L. and RYGE, G.: The Determination of Tear Energy of Extensible Materials of Dental Interest, $J$ Biomed Mater Res 2:281-296, 1968.

8. KORAN, A.; YU, R.; POWERS, J.M.; and CRAIG, R.G.: Color Stability of a Pigmented Elastomer for Maxillofacial Appliances, $J$ Dent Res 58:1450-1454, 1979.

9. DALBY, J. (Programmer): BMD8V, Analysis of Variance. Statistical Research Laboratory, University of Michigan, Ann Arbor, MI, 1968.

10. GUENTHER, W.C.: Analysis of Variance, Englewood Cliffs, NJ : Prentice Hall, 1964, 199 pp.

11. PENN, W.S.: PVC Technology, New York, NY: Wiley Interscience, $1971,177 \mathrm{pp}$. 